\title{
PERSONAL NEED FOR STRUCTURE AND READING COMPREHENSION IN A FOREIGN LANGUAGE
}

\author{
Daša MUNKOVÁ ${ }^{1}$, Eva STRANOVSKÁ ${ }^{1}$, Ivan SARMÁNY-SCHULLER ${ }^{2}$, Daniela MÜGLOVÁ ${ }^{1}$ \\ ${ }^{1}$ Faculty of Arts, Constantine the Philosopher University in Nitra \\ E-mail: \{dmunkova, estranovska,dmuglova\}@ukf.sk \\ ${ }^{2}$ Institute of Experimental Psychology, Slovak Academy of Sciences \\ Dúbravská cesta 9, 84104 Bratislava, Slovak Republic \\ E-mail: expssarm@savba.sk
}

\begin{abstract}
The aim of this study is to examine the relationship between the variables need for structure and reading comprehension skill in a foreign language. Specifically it aims to identify differences in the scores of examined variables in the following categories: foreign language (EN, $D E$ ) and faculty ( $p f, f f, f p v, c o m b i)$. For this reason, research was carried out in which 221 university students at CPU in Nitra participated. The PNS scale (Thomson et al., 2001) and tests of foreign language competence were used. The results showed that desire for structure correlates with reading comprehension skill negatively in the case of students of the Faculty of Arts. Need for structure correlates with study years of foreign language negatively in the case of students of the Faculty of Education. Statistically significant differences were proven in personal need for structure and response to lack of structure between the students of the Faculty of Arts and Natural Sciences.
\end{abstract}

Key words: personal need for structure, reading comprehension skill, foreign language, faculty

\section{INTRODUCTION}

The subject, personal need for structure, has been frequently examined in scientific literature, but mostly in terms of the relationship between personal need for structure and stereotypes, bias, ambiguity, tolerance, intolerance to ambiguity, anxiety or rigidity (Neuberg, Newsom, 1993; Sarmány-Schuller, 1999; Kruglanski, Webster, 1996, 200; Stangor, 2000; Thomson et al., 2001, and others). However, in the context of the linguistics vari-

This work was supported by the Slovak Research and Development Agency under the contract No. APVV-0451-10. able, the personal need for structure has not yet been explored deeply or analyzed in relation to reading comprehension skill. Stranovská et al. (2013) proved a negative relationship between the need for structure and verbal intelligence (the lower the personal need for structure, the higher verbal intelligence, see Stranovská et al., 2013).

Reading comprehension in a foreign language does not represent a uniform process. It is affected by language and cognitive processes. Ehlers (1998), through her findings, pointed out that the studies explaining or dealing with the effect of linguistic and cognitive variables on reading comprehension skill in a foreign language are absent. She sees further exploration in studies explain-

DOI: $10.21909 /$ sp.2014.03.660 
ing the relationships between cognitive and linguistic variables.

The focus of this study is to find out if there is a relationship between reading comprehension skill in a foreign language and need for structure as an individual's categorization activity. We want to investigate whether reading comprehension skill (understanding of texts written in foreign languages) is related to the desire for structure (simple organization of foreign-language texts) or is related to the response to lack of structure (response to cognitive load or response to unpredictable situations). Furthermore, we investigate the differences between the examined variables in the categories language (English EN and German $D E$ ) and faculty - (Faculty of Education $p f$, Faculty of Arts $f f$, Faculty of Natural Sciences $f p v$ and their combination combi). The major programs for which the students enrolled were teaching programs in the natural sciences, education, and arts. Foreign language study programs were minor obligatory courses in English and German languages, called English for Specific Academic Purposes or German for Specific Academic Purposes.

\section{A NEED FOR STRUCTURE AND}

\section{READING COMPREHENSION SKILL}

The cognitive individual variable personal need for structure is characterized by the representation of simplified information, generalization of previous experiences (Markus, Zajonc, 1985; Allport, 1954; Abelson, 1981; Bruner, 1957; Fiske, Taylor, 1991), organizing information into less complex categories, which an individual uses in new and ambiguous situations to preserve or keep his/her certainty (Neuberg, Newsom, 1993).
The research on personal need for structure is mainlyassociated with variables like stereotypes and bias (Neuberg, Newsom, 1993; Sarmány-Schuller, 1999; Stangor, 2000).Ahigh need for structure is related to the need for rapid, simple and exact responses and for diverting away from uncertain or ambiguous information(Kruglanski, Webster, 1996, 2000; Webster, Kruglanski, 1994). The individual feels uncomfortable and uncertain in uncertain situations (Thompson et al., 2001; Neuber et al., 1997; Neuberg, Newsom, 1993).

Neuberg and Newsom (1993) identified two conceptually different factors of need for structure-desire for structure (F1, to have a structured environment) and response to lack of structure (F2, an individual's response to lack of structure in a specific situation).

The first factor-desire for structure is referred to as the extent to which individuals want to establish a structure in their daily lives. Individuals with a high desire for structure prefer clear and structured way of life and a certain place for everything. The second factor-response to lack of structure is referred to as the extent to which individuals respond to unstructured, unpredictable situations. Individuals who expressively dislike uncertain situations or changes in their plans at the last moment achieve a high score in the response to lack of structure. The results of research studies conducted by Neuberg and Newsom (1993) indicate that both factors of the PNS scale are in different relationships to various individual features: response to lack of structure correlates with neuroticism and introversion, while desire for structure does not.

Steinmetzet al. (2011) proved that there is a stronger relationship between a rigidity scale and the factor desire for structure than the factor response to lack of structure. It can be 
explained by the fact that the first factor is mainly focused on "the need", or personal desire for a structured and known environment (situations), while the second factor is focused on "the response", or response to an unstructured and uncertain environment (situations). Healso proved that the factor response to lack of structure correlates with adaptability. He reasoned this because of the fact that response is closer to the way people "think" or how theynegotiate with an unstable environment(situations). A higher personal need for structure may represent lower adaptability and flexibility.

The psycholinguistic model of Goodman $(1967,1971)$ and Smith (1971) has a determining influence on the research of the linguistic variable foreign-language reading comprehension skill in cognitive psychology and linguistics. Goodman's universal hypothesis "reading in a mother tongue and in a foreign language are identical processes" stimulates the researchers to verify the following hypotheses:

1. Interdependency hypothesis: Reading comprehension skill in a foreign language depends on the cognitive skill of reading in the mother tongue, which the individual receives during development of the mother tongue (Bernhard, 1991; Coady, 1979; Hudson, 1982; Lee, Musumeci, 1988; Sarig, 1987; Eysenck, Keane, 2008; Sternberg, 2009).

2. Linguistic threshold hypothesis: Reading comprehension skill in a foreign language depends on language competence in that language. A student of a foreign language has to obtain a certain degree of control over a foreign language, or to overcome a language barrier in order to understand a text (Clarke, 1980; Cziko, 1978; Eskey, 1973; Devine, 1987; Allen et al., 1988; Rickheit et al., 2007; Rickheit et al., 2008).
Ehlers (1998) confirmed in her studies that the reading comprehension skill of foreign language students is not developed sufficiently. She stated that we could not expressly confirm whether reading comprehension skill is related to cognitive skill of reading in a mother tongue or whether it is related to foreign language competence. It is therefore associated with other factors such as learning context, target group, or the relationship between a source and a target language. She perceives the core of reading comprehension skill of the foreign language students as a degree of text understanding or misunderstanding. Steffensen et al. (1979), Taylor (1979), Johnson (1982), Carrell (1983), Steffensen (1986), McVee et al. (2005), Sternberg (2009) and others claim that foreign language knowledge is not sufficient for reading comprehension in that language; a reader needs have relevant general knowledge for a full text understanding. According to Ehlers (1998), the degree of text understanding depends on whether a reader disposes of a text schema and to what extent he/she can activate it. It is important for a reader not only to activate the received knowledge but also to use it and to connect it with new knowledge.

We assume that the intersection of the variables personal need for structure and reading comprehension skill may be connected to schema theory. Eysenck and Keane (2008) and Sternberg (2009) consider the schema theory essential in reading comprehension because it has a positive influence on understanding a text. It includes general knowledge files, i.e. knowledge about the world, events, people and their behaviors which we use in reading and listening comprehensions. According to Sternberg (2009), the schema theory is incidental to the 
processes of perception "top-down theories", focusing on the cognitive processes of higher levels, existing knowledge and expectations. Only afterwards do they move down to sensory information such as perception stimuli. Through interaction it leads to information exchange which influences the creation of mental representation itself on certain level. In the process of understanding, a reader creates relationships between entities and events mentioned in the sentence, whereby he/she uses knowledge saved in the long-term memory. If some information is not explicitly explained in the sentence, the reader has to draw on it through deduction or inference. In the case of misunderstanding, the reader does not know how to use knowledge and tends to assimilate the text. We assume that the way to deal with the uncertainty is related to the need for structure. An individual tends to obtain certainty through text modification into simpler forms; he/she wishes to avoid cognitive load in order to eliminate misunderstanding in dependence on language competence.

Recent studies (McVee et al., 2005; Schwarzová, 2009; Chan, Rao, 2010, and others) are focused on sociocultural and intercultural aspects. According to Schwarzová (2009), situational context and the recipient's general knowledge areessential for text understanding. Chan and Rao (2010) claim that schema consists of events or situational layers. McVee et al. (2005) present schema as existing knowledge, topic knowledge, prior and previous knowledge with sociocultural background based on discourse. In other words, schema is presented as a cultural tool used in relevant situations. According to McVee et al. (2005), the schema theory explains why a reader understands foreign texts with difficulty. Cultural differences exist between a reader and a text and also a different structure of knowledge are mutually dependent in determining a level of text understanding. He sees a reason for misunderstanding foreign language texts in the process of reading in reader's ungovernableness of essential cultural tools such as historical narratives.

We consider the support of students' intercultural consciousness to be essential for the understanding of foreign language texts. It depends on the student's knowledge structure whether he/she is dependent on simple schemas or if he/she is able to connect received knowledge with new knowledge and also use it appropriately in the situational context of the culture of the target language.

\section{METHOD}

\section{Participants}

Research was carried out at Constantine the Philosopher University in Nitra (CPU in Nitra) during the academic years 2011/2012, $2012 / 2013$ and $2013 / 2014$. It was attended by 221 students from different major study programs (students from the Faculty of Arts, Faculty of Natural Sciences and from the Faculty of Education). During their major study programs they had to be enrolled for a minor obligatory foreign language course (Foreign language for specific academic purposes - English/German). They were full-time students in the second year of study. The average age of students was 20.5 years. The students studied English for 9 years and German for 8 years on average.

\section{Hypotheses}

We assume a) a negative relationship between need for structure and reading com- 
prehension skill in a foreign language and b) that there are no differences between the examined categories (language or faculty) in terms of the score of examined variables (Reading comprehension, F1, F2 and PNS). These assumptions were verified by correlation analysis. We also used multivariate analysis of variance (MANOVA) for testing global null hypotheses stating:

H01: The values of variables in a vector of variables (Reading comprehension, F1 desire for structure, F2 - response to lack of structure and PNS - personal need for structure) do not depend on language ( $E N$, $D E)$;

H02: The values of variables in a vector of variables (Reading comprehension, F1, $F 2$ and $P N S$ ) do not depend on field of study - affiliation to faculty ( $p f$ - Faculty of Education, ff - Faculty of Arts, fpv - Faculty of Natural Sciences and their combination - combi).

\section{Measures}

PNS Scale (Authors: Thomson et al., 2001) - Personal need for structure arises from the assumption that the ability to reduce the uncertainty of a situation and cognitive load or to manage simplified information is connected with managing new situations. The scale consists of 12 items. We used the Slovak version of the PNS Scale (Author: Sarmány-Schuller, 1999). The PNS construct is based on a two-factor conception of personal need for structure:

1) desire for structure (sub-factor F1),

2) response to lack of structure (sub-factor F2).

Test of foreign language competence English, German. It tests foreign language competence and reading comprehension skill in a foreign language. The test consists of 74 items and measures the individual's ability in morphology, syntax, lexicology, culture studies, and reading comprehension. Tests (for the English and German language) were designed according to ISED 3 level B1/B2 for the entrance exams for studying foreign languages (English and German) at Constantine the Philosopher University in Nitra.

\section{ANALYSES AND RESULTS}

Table 1 depicts statistically significant correlations between examined variables $-F 1$, F2, PNS, reading comprehension skill, language competence and years of study. Relationships between examined variables are investigated separately for English and German. For English, the coefficients of correlation matrix (Table 2a) show a statistically significant positive relationship between foreign language competence and reading comprehension skill in a foreign language $(\mathrm{r}=.57)$ and a statistically significant negative relationship between desire for structure and number of years of learning English $(\mathrm{r}=$ -.19). For German, the coefficients of the correlation matrix (Table 2b) show a statistically significant positive relationship between foreign language competence and reading comprehension skill in a foreign language $(\mathrm{r}=.78)$ and a statistically significant negative relationship between desire for structure and foreign language competence $(\mathrm{r}=$ .21).

We also investigated (Table 3a, 3b, 3c, 3d) the relationships between examined variables according to the affiliation to faculty ( $p f$ Faculty of Education, ff - Faculty of Arts, $f p v$ - Faculty of Natural Sciences and their combination - combi). 
Table 1. Correlation matrix of examined variables - all participants $(n=221)$

\begin{tabular}{|l|l|c|c|c|c|c|}
\hline & $\begin{array}{c}\text { Years } \\
\text { of FL }\end{array}$ & $\begin{array}{c}\text { Language } \\
\text { competence }\end{array}$ & $\begin{array}{c}\text { Reading } \\
\text { comprehension }\end{array}$ & F1 & F2 & PNS \\
\hline Years of FL & 1.00 & 0.00 & 0.04 & $-0.16^{*}$ & -0.07 & -0.13 \\
\hline Language competence & 0.00 & 1.00 & $0.69^{* *}$ & -0.08 & 0.01 & -0.03 \\
\hline Reading comprehension & 0.04 & $0.69^{* *}$ & 1.00 & -0.06 & 0.00 & -0.03 \\
\hline F1 & $-0.16^{*}$ & -0.08 & -0.06 & 1.00 & $0.43^{* *}$ & $0.79^{* *}$ \\
\hline F2 & -0.07 & 0.01 & 0.00 & $0.43^{* *}$ & 1.00 & $0.90^{* * *}$ \\
\hline PNS & -0.13 & -0.03 & -0.03 & $0.79^{* *}$ & $0.90^{* * *}$ & 1.00 \\
\hline
\end{tabular}

Legend: Years of FL - number of years of foreign language learning, Language competence - score of the foreign language competence test, Reading comprehension - score of the reading comprehension test, $F 1$ - desire for structure, $F 2$ - response to lack of structure, $P N S$ - personal need for structure

$* \mathrm{p}<0.05, * * \mathrm{p}<0.01, * * * \mathrm{p}<0.001$

Table 2a. Correlation matrix of examined variables - English language $(n=121)$

\begin{tabular}{|l|l|c|c|c|c|c|}
\hline & $\begin{array}{c}\text { Years } \\
\text { of FL }\end{array}$ & $\begin{array}{c}\text { Language } \\
\text { competence }\end{array}$ & $\begin{array}{c}\text { Reading } \\
\text { comprehension }\end{array}$ & F1 & F2 & PNS \\
\hline Years of FL & 1.00 & -0.06 & -0.03 & $-0.19^{*}$ & -0.08 & -0.15 \\
\hline Language competence & -0.06 & 1.00 & $0.57^{* *}$ & 0.05 & 0.04 & 0.05 \\
\hline Reading comprehension & -0.03 & $0.57^{* *}$ & 1.00 & 0.06 & 0.05 & 0.06 \\
\hline F1 & $-0.19^{*}$ & 0.05 & 0.06 & 1.00 & $0.39^{*}$ & $0.77^{* *}$ \\
\hline F2 & -0.08 & 0.04 & 0.05 & $0.39^{*}$ & 1.00 & $0.89^{* * *}$ \\
\hline PNS & -0.15 & 0.05 & 0.06 & $0.77^{* *}$ & $0.89^{* * *}$ & 1.00 \\
\hline
\end{tabular}

Legend: Years of FL - number of years of foreign language learning, Language competence - score of the foreign language competence test, Reading comprehension - score of the reading comprehension test, $F 1$ - desire for structure, $F 2$ - response to lack of structure, $P N S$ - personal need for structure

$* \mathrm{p}<0.05, * * \mathrm{p}<0.01, * * * \mathrm{p}<0.001$

Table 2 b. Correlation matrix of examined variables - German language $(n=100)$

\begin{tabular}{|l|c|c|c|c|c|c|}
\hline & $\begin{array}{c}\text { Years } \\
\text { of FL }\end{array}$ & $\begin{array}{c}\text { Language } \\
\text { competence }\end{array}$ & $\begin{array}{c}\text { Reading } \\
\text { comprehension }\end{array}$ & F1 & F2 & PNS \\
\hline Years of FL & 1.00 & 0.00 & 0.06 & -0.11 & -0.07 & -0.10 \\
\hline Language competence & 0.00 & 1.00 & $0.78^{* *}$ & $-0.21^{*}$ & -0.05 & -0.13 \\
\hline Reading comprehension & 0.06 & $0.78^{* *}$ & 1.00 & -0.18 & -0.07 & -0.13 \\
\hline F1 & -0.11 & $-0.21^{*}$ & -0.18 & 1.00 & $0.49^{* *}$ & $0.81^{* *}$ \\
\hline F2 & -0.07 & -0.05 & -0.07 & $0.49^{* *}$ & 1.00 & $0.91^{* * *}$ \\
\hline PNS & -0.10 & -0.13 & -0.13 & $0.81^{* *}$ & $0.91^{* * *}$ & 1.00 \\
\hline
\end{tabular}

Legend: Years of FL - number of years of foreign language learning, Language competence - score of the foreign language competence test, Reading comprehension - score of the reading comprehension test, $F 1$ - desire for structure, $F 2$ - response to lack of structure, $P N S$ - personal need for structure

$* \mathrm{p}<0.05, * * \mathrm{p}<0.01, * * * \mathrm{p}<0.001$ 
Table 3a. Correlation matrix of examined variables - Faculty of Natural Sciences

\begin{tabular}{|l|c|c|c|c|c|c|}
\hline & $\begin{array}{c}\text { Years } \\
\text { of FL }\end{array}$ & $\begin{array}{c}\text { Language } \\
\text { competence }\end{array}$ & $\begin{array}{c}\text { Reading } \\
\text { comprehension }\end{array}$ & F1 & F2 & PNS \\
\hline Years of FL & 1.00 & -0.10 & -0.01 & -0.29 & -0.14 & -0.25 \\
\hline Language competence & -0.10 & 1.00 & $0.57^{* *}$ & 0.23 & 0.17 & 0.24 \\
\hline Reading comprehension & -0.01 & $0.57^{* *}$ & 1.00 & 0.19 & -0.03 & 0.09 \\
\hline F1 & -0.29 & 0.23 & 0.19 & 1.00 & $0.37^{*}$ & $0.79^{* *}$ \\
\hline F2 & -0.14 & 0.17 & -0.03 & $0.37^{*}$ & 1.00 & $0.86^{* *}$ \\
\hline PNS & -0.25 & 0.24 & 0.09 & $0.79^{* *}$ & $0.86^{* *}$ & 1.00 \\
\hline
\end{tabular}

Legend: Years of $F L$ - number of years of foreign language learning, Language competence - score of the foreign language competence test, Reading comprehension - score of the reading comprehension test, $F 1$ - desire for structure, $F 2$ - response to lack of structure, $P N S$ - personal need for structure

$* \mathrm{p}<0.05, * * \mathrm{p}<0.01$

Table 3b. Correlation matrix of examined variables - Faculty of Arts

\begin{tabular}{|l|c|c|c|c|c|c|}
\hline & $\begin{array}{c}\text { Years } \\
\text { of FL }\end{array}$ & $\begin{array}{c}\text { Language } \\
\text { competence }\end{array}$ & $\begin{array}{c}\text { Reading } \\
\text { comprehension }\end{array}$ & F1 & F2 & PNS \\
\hline Years of FL & 1.00 & 0.06 & 0.06 & 0.06 & 0.11 & 0.10 \\
\hline Language competence & 0.06 & 1.00 & $0.91^{* * *}$ & $-0.45^{* *}$ & 0.05 & -0.17 \\
\hline Reading comprehension & 0.06 & $0.91^{* * *}$ & 1.00 & $-0.46^{* *}$ & -0.06 & -0.24 \\
\hline F1 & 0.06 & $-0.45^{* *}$ & $-0.46^{* *}$ & 1.00 & $0.58^{* *}$ & $0.84^{* *}$ \\
\hline F2 & 0.11 & 0.05 & -0.06 & $0.58^{* *}$ & 1.00 & $0.93^{* * *}$ \\
\hline PNS & 0.10 & -0.17 & -0.24 & $0.84^{* *}$ & $0.93^{* * *}$ & 1.00 \\
\hline
\end{tabular}

Legend: Years of $F L$ - number of years of foreign language learning, Language competence - score of the foreign language competence test, Reading comprehension - score of the reading comprehension test, $F 1$ - desire for structure, $F 2$ - response to lack of structure, $P N S$ - personal need for structure

$* * \mathrm{p}<0.01, * * * \mathrm{p}<0.001$

Table 3c. Correlation matrix of examined variables - Faculty of Education

\begin{tabular}{|l|c|c|c|c|c|c|}
\hline & $\begin{array}{c}\text { Years } \\
\text { of FL }\end{array}$ & $\begin{array}{c}\text { Language } \\
\text { competence }\end{array}$ & $\begin{array}{c}\text { Reading } \\
\text { comprehension }\end{array}$ & F1 & F2 & PNS \\
\hline Years of FL & 1.00 & 0.11 & 0.10 & $-0.27^{*}$ & $-0.20^{*}$ & $-0.27^{*}$ \\
\hline Language competence & 0.11 & 1.00 & $0.73^{* *}$ & $-0.26^{*}$ & -0.01 & -0.13 \\
\hline Reading comprehension & 0.10 & $0.73^{* *}$ & 1.00 & -0.07 & 0.06 & 0.01 \\
\hline F1 & $-0.27^{*}$ & $-0.26^{*}$ & -0.07 & 1.00 & $0.43^{* *}$ & $0.79^{* *}$ \\
\hline F2 & $-0.20^{*}$ & -0.01 & 0.06 & $0.43^{* *}$ & 1.00 & $0.89^{* * *}$ \\
\hline PNS & $-0.27^{*}$ & -0.13 & 0.01 & $0.79^{* *}$ & $0.89^{* * *}$ & 1.00 \\
\hline
\end{tabular}

Legend: Years of FL - number of years of foreign language learning, Language competence - score of the foreign language competence test, Reading comprehension - score of the reading comprehension test, $F 1$ - desire for structure, $F 2$ - response to lack of structure, $P N S$ - personal need for structure

$* \mathrm{p}<0.05, * * \mathrm{p}<0.01, * * * \mathrm{p}<0.001$ 
Table 3d. Correlation matrix of examined variables - Combination

\begin{tabular}{|l|c|c|c|c|c|c|}
\hline & $\begin{array}{c}\text { Years } \\
\text { of FL }\end{array}$ & $\begin{array}{c}\text { Language } \\
\text { competence }\end{array}$ & $\begin{array}{c}\text { Reading } \\
\text { comprehension }\end{array}$ & F1 & F2 & PNS \\
\hline Years of FL & 1.00 & 0.01 & -0.02 & 0.09 & 0.16 & 0.16 \\
\hline Language competence & 0.01 & 1.00 & $0.63^{* *}$ & 0.12 & -0.09 & -0.01 \\
\hline Reading comprehension & -0.02 & $0.63^{* *}$ & 1.00 & -0.10 & -0.07 & -0.09 \\
\hline F1 & 0.09 & 0.12 & -0.10 & 1.00 & $0.38^{*}$ & $0.74^{* *}$ \\
\hline F2 & 0.16 & -0.09 & -0.07 & $0.38^{*}$ & 1.00 & $0.90^{* * *}$ \\
\hline PNS & 0.16 & -0.01 & -0.09 & $0.74^{* *}$ & $0.90^{* * *}$ & 1.00 \\
\hline
\end{tabular}

Legend: Years of FL - number of years of foreign language learning, Language competence - score of the foreign language competence test, Reading comprehension - score of the reading comprehension test, $F 1$ - desire for structure, $F 2$ - response to lack of structure, $P N S$ - personal need for structure

$* \mathrm{p}<0.05, * * \mathrm{p}<0.01, * * * \mathrm{p}<0.001$

In the category - fpv-Faculty of Natural Sciences, a statistically significant relationship between need for structure and reading comprehension skill in a foreign language or number of years of foreign language learning was not proved. We found only a statistically significant positive relationship between foreign language competence and reading comprehension skill in a foreign language $(\mathrm{r}=.57)$.

In the category - ff - Faculty of Arts, we found a statistically significant negative relationship between desire for structure and foreign language competence $(\mathrm{r}=-.45)$, a statistically significant negative relationship between desire for structure and reading comprehension skill in a foreign language $(\mathrm{r}=-.45)$ and a statistically significant positive relationship between foreign language competence and reading comprehension skill in a foreign language $(\mathrm{r}=.91)$.

In the category - pf - Faculty of Education, a statistically significant negative relationship between desire for structure and foreign language competence $(\mathrm{r}=-.26)$ was proved, a statistically significant negative relationship between desire for structure and number of years of foreign language learning $(\mathrm{r}=-.27)$, a statistically significant negative relationship between response to lack of structure and number of years of foreign language learning $(\mathrm{r}=-.20)$, and a statistically significant negative relationship between personal need for structure and number of years of foreign language learning $(\mathrm{r}=-.27)$. Also, a statistically significant positive relationship between foreign language competence and reading comprehension skill in a foreign language $(\mathrm{r}=.73)$ was proved.

In the category - combi (students studying at two faculties) - a statistically significant positive relationship between foreign language competence and reading comprehension skill in a foreign language was proved. However, a statistically significant relationship between cognitive-individual variables and reading comprehension skill in a foreign language was not proved.

Based on the results of multivariate analysis of variance (Table 4 ), we rejected the null hypotheses at the $0.1 \%$ significance level for the category language and at the 5\% significance level for the category faculty. There 
Table 4. Multivariate analysis of variance (MANOVA)

\begin{tabular}{|l|c|c|c|c|c|c|}
\hline & Test & Value & F & Effect df & Error df & $\mathrm{p}$ \\
\hline Intercept & Roy's & 24.316 & 1734.590 & 3 & 214.0000 & 0.000 \\
\hline Language & Roy's & 0.109 & 7.845 & 3 & 214.0000 & 0.000 \\
\hline Faculty & Roy's & 0.037 & 2.670 & 3 & 216.0000 & 0.048 \\
\hline
\end{tabular}

is a statistically significant difference between languages $(E N, D E)$ in terms of the score of individual variables $(F 1, F 2, P N S$, reading comprehension) and also among faculties ( $p f$-Faculty of Education, $f f-F a c$ ulty of Arts, fpv - Faculty of Natural Sciences and their combination - combi) in terms of the score of individual variables $(F 1, F 2$, $P N S$, reading comprehension), i.e. in one variable at least.

From the multiple comparison (Tukey's HSD test, Table 5), homogenous groups were identified (Hvorecký et al., 2010). We identified statistically significant differences in the score of individual variables $(F 1, F 2, P N S$ and reading comprehension) between languages. We found a statistically significant difference between English and German in the variable reading comprehension skill. There are no statistically significant differences in the score of $F 1$ (desire for structure), F2 (response to lack of structure) and PNS (personal need for structure) between English and German.

Table 5. Multiple comparison (Tukey's HSD test) - Foreign language (Reading comprehension, F1, F2, PNS)

\begin{tabular}{|l|c|c|c|}
\hline Language & $\begin{array}{c}\text { Reading comprehension test score } \\
\text { Mean }\end{array}$ & 1 & 2 \\
\hline DE & 1.810 & $* * * *$ & \\
\hline EN & 3.487 & & $* * * *$ \\
\hline
\end{tabular}

\begin{tabular}{|l|c|c|}
\hline Language & $\begin{array}{c}\text { F1 } \\
\text { Mean }\end{array}$ & 1 \\
\hline EN & 16.429 & $* * * *$ \\
\hline DE & 17.080 & $* * * *$ \\
\hline
\end{tabular}

\begin{tabular}{|l|c|c|}
\hline Language & $\begin{array}{c}\text { F2 } \\
\text { Mean }\end{array}$ & 1 \\
\hline DE & 27.000 & $* * * *$ \\
\hline EN & 27.173 & $* * * *$ \\
\hline
\end{tabular}

\begin{tabular}{|l|c|c|}
\hline Language & $\begin{array}{c}\text { PNS } \\
\text { Mean }\end{array}$ & 1 \\
\hline DE & 43.603 & $* * * *$ \\
\hline EN & 44.080 & $* * * *$ \\
\hline
\end{tabular}


Table 6. Multiple comparison (Tukey's HSD test) - Faculty (Reading comprehension, F1, F2, PNS)

\begin{tabular}{|l|c|c|c|}
\hline Faculty & $\begin{array}{c}\text { Reading comprehension test score } \\
\text { Mean }\end{array}$ & 1 & 2 \\
\hline $\mathrm{pf}$ & 2.435 & $* * * *$ & \\
\hline $\mathrm{fpv}$ & 2.562 & $* * * *$ & $* * * *$ \\
\hline $\mathrm{ff}$ & 2.826 & $* * * *$ & $* * * *$ \\
\hline combi & 3.327 & & $* * * *$ \\
\hline
\end{tabular}

\begin{tabular}{|l|c|c|}
\hline Faculty & $\begin{array}{c}\text { F1 } \\
\text { Mean }\end{array}$ & 1 \\
\hline fpv & 16.000 & $* * * *$ \\
\hline pf & 16.546 & $* * * *$ \\
\hline combi & 17.103 & $* * * *$ \\
\hline ff & 17.608 & $* * * *$ \\
\hline
\end{tabular}

\begin{tabular}{|l|c|c|c|}
\hline Faculty & F2 & 1 & 2 \\
\hline fpv & 26.281 & $* * * *$ & \\
\hline pf & 26.944 & $* * * *$ & $* * * *$ \\
\hline combi & 27.017 & $* * * *$ & $* * * *$ \\
\hline ff & 29.130 & & $* * * *$ \\
\hline
\end{tabular}

\begin{tabular}{|l|c|c|c|}
\hline Faculty & $\begin{array}{c}\text { PNS } \\
\text { Mean }\end{array}$ & 1 & 2 \\
\hline fpv & 42.281 & $* * * *$ & \\
\hline pf & 43.490 & $* * * *$ & $* * * *$ \\
\hline combi & 44.120 & $* * * *$ & $* * * *$ \\
\hline ff & 46.739 & & $* * * *$ \\
\hline
\end{tabular}

From the multiple comparison (Tukey's HSD test, Table 6), we identified statistically significant differences in the score of individual variables $(F 1, F 2, P N S$ and reading comprehension) among faculties ( $p f-F a c-$ ulty of Education, ff - Faculty of Arts, fpv Faculty of Natural Sciences and their combination - combi).

In the case of the variable reading comprehension skill a statistically significant difference between the Faculty of Educa- tion (pf) and their combination (combi) was proved.

In the case of variables $F 2$ (response to lack of structure) and PNS (personal need for structure), statistically significant differences between the Faculty of Natural Sciences (fpv) and Faculty of Arts (ff) were proved.

In the case of variable $F 1$ (desire for structure) no statistically significant differences among faculties were proved. 


\section{DISCUSSIONAND CONCLUSION}

In our study we attempted to contribute to the research on the need for structure with relationship to language variables such as reading comprehension skill. We focused primarily on an investigation of the relationship between personal need for structure and reading comprehension skill in a foreign language. We also examined the need for structure in relation to foreign language competence and to the number of years of foreign language learning. The focus of our research was on finding differences within the personal need for structure and reading comprehension skill in a foreign language in two categories - foreign language (between English and German) and faculty (Faculty of Arts, Faculty of Education, Faculty of Natural Sciences and their combination).

We found a statistically significant dependence (relationship) between reading comprehension skill in a foreign language and foreign language competence, i.e. the higher the foreign language competence, the higher the reading comprehension skill. Students' reading comprehension skill in a foreign language is affected by their level of foreign language competence. Our results confirmed the linguistic threshold hypothesis as Clarke (1980), Cziko (1978), Eskey (1973), Devine (1987), Allen et al. (1988), Rickheit et al. (2007) and Rickheit et al. (2008), who found that students of foreign languages have to firstly possess a certain level of language competence in foreign languages to understand a text. We share the same opinion as Clarke (1980) that foreign language competence is a crucial variable of reading comprehension skill in a foreign language.
Results also showed that the need for structure (subfactor F1- desire for structure) is related to foreign language competence and to the number of years of foreign language learning in both categories (foreign language and faculty), namely a statistically significant negative correlation between desire for structure and foreign language competence by students of German $(\mathrm{r}=-.21)$, a statistically significant negative correlation between desire for structure and foreign language competence by students of the Faculty of Arts $(\mathrm{r}=-.45)$ and a statistically significant negative correlation between desire for structure and foreign language competence by students of the Faculty of Education $(\mathrm{r}=-.26)$. The lower the desire for structure, the higher the foreign language competence displayed by students of the Faculty of Arts and the Faculty of Education. In comparison to foreign languages, the lower the desire for structure, the higher the foreign language competence of students of German language and vice versa.

The Need for structure is also related to the number of years of foreign language learning. It decreases with an increasing number of years of foreign language learning by students of the Faculty of Education (a negative correlation between desire for structure and the number of years of foreign language learning). The more years they learn a foreign language, the less desire for structure.

Personal need for structure decreases with an increasing test score of foreign language competence and with the number of years of foreign language learning. It means that desire for structure is related to a certain level of uncertainty in the dependence on the level of foreign language competence and the number of years of foreign language learn- 
ing. Foreign language and understanding (reading comprehension) may mean stress (stress situation) or uncertainty for students who have not sufficiently absorbed the structure of a foreign language. According to John et al. (2000), uncertainty cannot be eliminated from the process of foreign language learning but its influence and the degree to which it can be minimized, can be examined. The results of our research showed that the uncertainty can be minimized with the level of foreign language competence and with the number of years of foreign language learning. Brown (2000) recommends teaching individuals to tolerate ambiguity (intuitive behavior, not searching for rules in every sentence) and to accept it as a part of the foreign language learning process. We share the research results from SarmánySchuller (1997, 1999, and 2001), Fujimoto et al. (2005) and Bouckenhooghe et al. (2007) which pointed out that the need for structure is associated with the ability to solve new ambiguous situations, i.e. to change established ways of behaviors, thinking, attitudes or simple structures.

The assumption of a negative relationship between the personal need for structure and reading comprehension skill in a foreign language was confirmed in the case of the sub-factor F1 (desire for structure). There is a negative correlation between reading comprehension skill in a foreign language and desire for structure by students of the Faculty of Arts $(\mathrm{r}=-.46)$, i.e. the lower the desire for structure, the higher the reading comprehension skill and vice versa. The less cognitive load experienced by students of the Faculty of Arts in managing information from reading a foreign text, the more they notice semantic, pragmatic and extra textual indicators in the text (cultural specifics, sec- ondary meanings etc.). It is noteworthy that only the subfactor - desire for structure - is related to reading comprehension skill and not the second subfactor - response to lack of structure. Our research result supports Steinmetz et al.'s claim (2011) that desire for structure is more focused on "the need" for structured or known information in comparison to the response to lack of structure. In our case, desire for structure is aimed at the need for managing information (structured and organized knowledge) and its simplification or not in the process of reading comprehension in a foreign language.

The second substantial fact is that a statistically significant negative correlation was proved only by students of the Faculty of Arts. No significant correlations between the desire for structure and reading comprehension skill by students of other faculties were proved. However, there is no statistically significant difference among faculties in terms of the score of the variable desire for structure. This fact can be explained by the field of study (study programs). Students of the Faculty of Arts are more familiar with handling relevant general knowledge (from history, philosophy, etc.), i.e. the schema theory has a positive influence on their understanding of a foreign language text.

Personal need for structure, especially the subfactor - response to lack of structure points to differences between students studying at the Faculty of Arts $(f f)$ and the Faculty of Natural Sciences $(f p v)$.

There are statistically significant differences in the score of response to lack of structure and in the score of personal need for structure between the students of the Faculty of Natural Sciences $(f p v)$ and the Faculty of Arts ( $f f)$. Students studying at the Faculty of Arts achieved a higher score in 
the need for structure and response to lack of structure than students studying at the Faculty of Natural Sciences. Students studying at the Faculty of Arts process new information differently, they have a social sciences background. On the other hand, students studying at the Faculty of Natural Sciences prefer analytical thinking, which is often connected to the ability "to handle numbers” (Švecová, Paulovičová, 2012).

We assumed that the variables - reading comprehension, desire for structure, response to lack of structure and personal need for structure - depend neither on language $(E N / D E)$ nor on faculty ( $p f, f f$, $f p v$ and combi) - field of study.

The analysis results showed that personal need for structure does not depend on the language being learned by students. We expected that the need for structure would have an influence on German competence as German is structured into strict rules and exceptions (more so than English). Therefore, the question arises if students studying foreign languages really need a structure or if this only applies to students studying foreign languages as an obligatory course.

Reading comprehension in English is different from German, while the score of the test of reading comprehension in English is higher than German. We associate it with the level of foreign language competence and the number of years of foreign language learning.

It was shown that the ability of reading comprehension depends on the faculty, i.e. on the field of study (study programs). Students studying at the Faculty of Education $(p f)$ achieved a lower score in the reading comprehension test than students studying at two faculties (combi). We believe that this may be related to the level of foreign lan- guage competence. In our research, students from the Faculty of Education are perceived as having a low foreign language competence, which has an influence on their reading comprehension skill.

We can summarize the results of our research as follows: foreign language competence and the number of years of foreign language learning can be expressed as essential variables affecting the need for structure and reading comprehension skill in foreign languages. Also, the level of reading comprehension in a foreign language affects the need for structure.

The future direction of our research will focus on analyzing need for structure and language variables by linguistic students (philologists and future foreign language teachers); also on the determination of the dynamics and stability of the need for structure in dependence on training foreign language competence through a linguistic intervention program, which works with various simulations of social situations in the foreign language education process, whereby ambiguous or uncertain situations are taken into account.

Received March 5, 2014

\section{REFERENCES}

ABELSON, R.P., 1981, The psychological status of the script concept. American Psychologist, 36, 715-729.

ALLEN, E.D., BERNHARDT, E.B., BERRY, M.T., DEMEL, M., 1988, Comprehension and text genre: An analysis of secondary school foreign language readers. Modern Language Journal, 72, 163172 .

ALLPORT, G.W., 1954, The nature of prejudice reading. MA: Addison-Wesley.

BEHRMANN, M.M., 2002, Beginning reading and Phonological Awareness for Students with Learning Disability. [2014-01-15]. Available at: 
http://www.kidsource.com/kidsource/content2/ disability.phonological.htm

BERNHARDT, E.B., 1991, Reading development in a second language: Theoretical, empirical, and classroom perspectives. Norwood, NJ: Ablex.

BOUCKENOOGHE, D., VANDERHEYDEN, K., VAN LAETHEM, S., MESTDAGH, S., 2007, Cognitive motivation correlates of coping style in decisional conflict. Journal of Psychology - Interdisciplinary and Applied, 141, 605-625.

BOWEY, J.A., MCGUIGAN, M., RUSCHENA, A., 2005, On the association between serial naming speed for letters and digits and word-reading skill: Towards a developmental account. Journal of Research in Reading, 28, 4, 400-422.

BROWN, H.D., 2000, Principles of language learning and teaching (4th ed.). New York: Longman.

BRUNER, J.S., 1957, Going beyond the information given. In: H. Gruber, G. Terrell, M Wertheimer (Eds.), Contemporary approaches to cognition (pp. 41-69). Cambridge, MA: Harvard University Press

CARRELL, P.L., 1983, Three components of background knowledge in reading comprehension. Language Learning. Applied Linguistics, 33, 2, 183 207.

CHAN, C.K.K., RAO, N., 2010, Revisiting the Chinese learner - changing contexts, changing education. Sociocultural perspectives on Schema Theory. CERC Studies in Comparative Education, 25, 133-167.

CLARKE, M.A., 1980, The short circuit hypothesis of ESL reading - or when language competence interferes with reading. The Modern Language Journal, 64, 1, 203-210.

COADY, J., 1979, A psycholinguistic model of the ESL reader. In: R. Mackay, B. Barkman, R.R. Jordan (Eds.), Reading in a second language (pp. 5-12). Rowley, MA: Newbury House.

CZIKO, G.A., 1978, Differences in first- and second-language reading: The use of syntactic, semantic and discourse constraints. Canadian Modern Language Review, 34, 479-489.

DEVINE, J., 1987, General language competence and adult second language reading. In: J. Devine et al. (Eds.), Research in reading English as a second language (pp. 73-86). Washington, DC: Teaching English to Speakers of Other Languages.

EHLERS, S., 1998, Lesetheorie und fremdsprachliche Lesepraxis aus der Perspektive des
Deutschen als Fremdsprache. Tübingen: Gunter Narr Verlag.

ELBRO, C., SCARBOROUGH, H.S., 2003, Early identification. In: P. Bryant, T. Nunes (Eds.), Handbook of children's reading (pp. 339-359). Dordrecht: Kluwer Academic.

ESKEY, D.E., 1973, A model program for teaching advanced reading to students of English as a foreign language. Language Learning, 23, 2, 169184.

EYSENCK, M.V., KEANE, M.T., 2008, Kognitivni psychologie. Praha: Academia.

FISKE, S.X, TAYLOR, S.E., 1991, Social cognition. New York: McGraw-Hill.

FUJIMOTO, Y., HARTEL, C.E.J., PANIPUCCI, D., 2005, Emotional experience of individualistcollectivist workgroups: Findings from the study of 14 multinationals located in Australia. In: C.E. Hartel, W.J. Zerbe, N.M. Ashkanasy (Eds.), Emotions in organizational behavior. Mahwah, N.J.: Lawrence Erlbaum.

GOODMAN, K., 1967, Reading: A psycholinguistic guessing game. Journal of the Reading Specialist, 6, 126-135.

GOODMAN, K.S, 1971, Psycholinguistic universals in the reading process. In: P. Pimsleur, T. Quinn (Eds.), The psychology of second language learning (pp. 135-142). Cambridge: Cambridge University Press.

HUDSON, T, 1982, The effects of induced schemata on the "short circuit" in L2 reading: Nondecoding factors in L2 reading performance. Language Learning, 32, 1-31.

HVORECKÝ, J., DRLÍK, M., MUNK, M., 2010, The effect of visual query languages on the improvement of information retrieval skills. Procedia-Social and Behavioral Sciences, 2, 2, 717 723.

JOHN, M.J., CALLAN, S., PROCTOR, S., HOLSTE, S., 2000, Tactical decision-making under uncertainty: Experiments I and II, TR 1821. Space and Naval Warfare Systems Center, San Diego, CA.

JOHNSON, P., 1982, Effects on reading comprehension of building background. TESOL Quarterly, 16, 4, 503-516.

KRUGLANSKI, A.W., THOMPSON, E.P., HIGGINS, E.T., ATASH N. N., PIERRO, A., SHAH, J.Y., SPIEGEL, S., 2000, To "do the right thing" or to "just do it": Locomotion and assessment as distinct self-regulatory imperatives. Journal of Personality and Social Psychology, 79, 793815. 
KRUGLANSKI, A.W., WEBSTER, D.M., 1996, Motivated closing of the mind: "Seizing" and "freezing”. Psychological Review, 103, 263-283.

LEE, J.F., MUSUMECI, D., 1988, On Hierarchies of Reading Skills and Text Types. Modern Language Journal, 72, 173-187.

MARKUS, H., ZAJONC, R.B., 1985, The cognitive perspective in social psychology. In: G. Lindzey, E. Aronson (Eds.), Handbook of social psychology (pp. 137-230). NY: Random House.

McVEE M.B., DUNSMORE, K., GAVELEK, J.R., 2005, Schema Theory Revisited. Review of Educational Research, 75, 4, 531-566.

NEUBERG, S.L., NEWSOM, J.T., 1993, Personal need for structure: Individual differences in the desire for simple structure. Journal of Personality and Social Psychology, 65, 113-131.

NEUBERG, S.L., WEST, S.G., JUDICE, T.N., THOMPSON, M.M., 1997, On dimensionality, discriminant validity, and the role of psychometric analyses in personality theory and measurement: Reply to Kruglanski et al.'s (1997) defence of the Need for Closure Scale. Journal of Personality and Social Psychology, 73, 5, 1017-1029.

SARIG, G., 1987, High-level reading in the first and in the foreign language: Some comparative process data. In: J. Devine, P. Carrell, D. Eskey (Eds.), Research in reading in English as a second language (pp. 105-120). Washington, DC, TESOL Text.

SARMÁNY-SCHULLER, I., 1997, Integrálne výsledky výskumov kognitívnych štýlov a praktická inteligencia. In: I. Sarmány-Schuller, I. Ruisel (Eds.), Zbornik Praktická inteligencia IV., ÚEPs SAV, Bratislava.

SARMÁNY-SCHULLER, I., 1999, Neistota istota / prípad kauzálnej neistoty. In: I. SarmánySchuller, M. Bratská, E. Naništová (Eds.), Reflexie súčasnej psychológie na Slovensku, Zbornik príspevkov IX. zjazdu slovenských psychológov, Bratislava: Stimul.

SARMÁNY-SCHULLER, I., 1999, Procrastination, need for cognition and sensation seeking. Studia Psychologica, 41, 1, 73-85.

SARMÁNY-SCHULLER, I., 2001, Potreba štruktúry a schopnost' vytvárania štruktúry ako osobnostné konštrukty. In: I. Sarmány Schuller (Eds.), Zbornik Psychológia pre bezpečný svet, Trenčín. Bratislava: Stimul.

SCHWARZOVÁ, M., 2009, Úvod do kognitívní lingvistiky. Praha: Dauphin.

SMITH, F., 1971, Understanding reading. New. York: Holt, Rinehart \& Winston.

SMITH-SPARK, J.H., FISK, J.E., 2007, Working memory functioning in developmental dyslexia. Memory, 15, 1, 34-56.

STANGOR, C., 2000, Stereotypes and prejudice. New York: Psychology Press.

STEFFENSEN, M.S., JOAG-DEV, C., ANDERSON, R.C., 1979, A cross-cultural perspective on reading comprehension. Reading Rewarch Qttarfedy, 15, 10-29.

STEFFENSEN, M., 1986, Register, cohesion and reading comprehension. Applied Linguistics, 7, 1, 71-85.

STEINMETZ, J.P., LOARER, E., HOUSSEMAND, C., 2011, Rigidity of attitudes and behaviors: A study on the validity of the concept. Individual Differences Research, 9, 84-106.

STERNBERG, R.J., 2009, Kognitivni psychologie. Praha: Portál.

STRANOVSKÁ, E., MUNKOVÁ, D., MUNK, M., SARMÁNY-SCHULLER, I., 2013, Cognitive-individual, linguistic and demographic variables, and syntactic abilities in foreign language. Studia Psychologica, 55, 4, 273-287.

ŠVECOVÁ, V., PAVLOVIČOVÁ, G., 2012, Reflection of pupil's models of numbers in mental map. Procedia-Social and Behavioral Sciences, 46, 5311-5314.

TAYLOR, B., 1979, Good and poor readers' recall of familiar and unfamiliar text. Journal of Reading Behavior, 11, 375-388.

THOMPSON, M.M., NACCARATO, M.E., PARKER, K.C.H., MOSKOWITZ, G., 2001, The Personal Need for Structure (PNS) and Personal Fear of Invalidity (PFI) scales: Historical perspectives, present applications and future directions. In: G. Moskowitz (Eds.), Cognitive social psychology: The Princeton symposium on the legacy and future of social cognition, Mahwah, NJ: Erlbaum. 


\section{OSOBNÁ POTREBA ŠTRUKTÚRY A ČÍTANIE S POROZUMENÍM V CUDZOM JAZYKU}

D. Munková,E. Stranovská, I. S a r mány-S chu 11 e r, D. M üg 1 ová

Súhrn: Ciel'om štúdie je skúmanie vzt'ahu medzi potrebou štruktúry a čítaním s porozumením $v$ cudzom jazyku a identifikovat' rozdiely jednotlivých premenných na úrovni faktorov: cudzi jazyk $(D E, E N)$ a fakulta $(p f, f f, f p v, c o m b i)$. Na vzorke 221 študentov Univerzity Konštantína Filozofa v Nitre boli použité výskumné metódy škála PNS (Thomson a kol., 2001) a testy cudzojazyčnej spôsobilosti. Výsledky ukázali, že želanie štruktúry negatívne koreluje s čítaním s porozumením u študentov Filozofickej fakulty. Potreba štruktúry negatívne koreluje s dĺžkou štúdia cudzieho jazyka u študentov Pedagogickej fakulty. Štatisticky významné rozdielnosti v osobnej potrebe štruktúry a v reakcii na chýbanie štruktúry sa ukázali medzi študentmi Filozofickej fakulty a Fakulty prírodných vied. 